\title{
Convergence of inflation with a common cycle: estimating and modelling Spanish historical inflation from the 16 th to the 18 th centuries
}

\author{
José Luis Cendejas Bueno \\ Instituto de Investigaciones Económicas y Sociales "Francisco de Vitoria" \\ Universidad Francisco de Vitoria \\ Carretera M-515, Pozuelo-Majadahonda, Km. 1,800 \\ 28223 Pozuelo de Alarcón (Madrid) SPAIN \\ Corresponding author: joseluis.cendejas@iies-fv.es \\ Phone number: (0034) 917091400 \\ Fax: (0034) 917091554 \\ Cecilia Font de Villanueva \\ Instituto de Investigaciones Económicas y Sociales "Francisco de Vitoria" \\ Universidad Francisco de Vitoria \\ Carretera M-515, Pozuelo-Majadahonda, Km. 1,800 \\ 28223 Pozuelo de Alarcón (Madrid) SPAIN
}

\begin{abstract}
The aim of this paper is twofold. First, to obtain inflation rates for the four regions of Spain analyzed for the period 1501 to 1800 by modeling Hamilton's (1934, 1947) price index series by means of an unobserved component model with a common cyclical factor. And second, to prove their long term convergence process. Therefore convergence concerns both the cyclical variation of inflation rates common to the four regions, and trend inflation. A complete convergence of the trend inflation occurred once the monetary reforms of Charles II of Spain were introduced in order to redress the previous monetary instability known as inflation of the vellon. The predominance of the vellón in small change and the concentration of the influx of silver when inflation was comparatively lower (second half of the sixteenth century and the seventeenth century) complicate to reach simple conclusions on the monetary origin of inflation exclusively based on precious metals, but, on the contrary, suggests a monetary origin based on copper coin and fiscal distortions. So, monetary stability proved to be a necessary condition for inflation convergence and the fulfillment of the purchasing power parity condition along the eighteen century.
\end{abstract}

Keywords convergence of inflation, common cyclical factor, unobserved component models, Hamilton's price series, inflation of the vellón

JEL Classification C32, E31, E32, E42 


\section{Introduction}

The works of Hamilton $(1934,1947)$ are one of the main references for analysing the economic and monetary history of Spain. Hamilton built several series of price indexes spanning the 16th to 18th centuries, and made a detailed analysis of the link between prices and the prevailing circumstances, mainly of monetary type. As far as monetary factors are concerned, Hamilton paid attention to the effects of the influx of precious metals (gold, and above all, silver) from America and its introduction into the Spanish economy. One of Hamilton's main contribution consists of building regional price indexes for Spain over a long period of time, based on disaggregated information taken from original sources, mainly books of accounts of hospitals and monasteries.

Theories developed to explain the overall economic process in Europe known as "merchant capitalism" have been based to a great extent in the analysis of inflation in modern history. Hamilton himself coined the term "profit inflation" (Hamilton 1929) to describe how the increase of prices above wages and other expenses were the cause of the initial rise of capitalism. The controversy following Hamilton's theories on the causes and effects of the "price revolution" illustrate how fertile his work was. The number of papers subsequently written on the subject cannot be cited here. Munro (2007) has made an excellent summary of these debates. See also González and Hoyo (1983) for their effects on economic thought and García de Paso $(1999,2002)$ and Sargent and Velde (2002) concerning monetary theory.

With regard to prices, reference should be made to other papers also based on Hamilton's price indexes, although the aim of these has been to build a series of weighted price indexes for a representative basket of consumer goods (Hamilton used arithmetic means to construct his indexes). Martín Aceña (1992) constructs a price index for New Castile comparable with those made for other regions of Europe for the period from 1500 to 1700 . Based on this index, he was able to compare the magnitude of the "price revolution" and to offer an explanation based on the quantity theory of money. Using, among other data, Hamilton's tables for the period, Reher and Ballesteros (1993) consider price, wage and real wage indexes for Madrid between 1501 and 1991. Based on these, they were able to analyse the mid and long run evolution of prices and wages, and to compare trends with those of England. Llopis et al. (2000) built a series of weighted price indexes for the north-western regions of Castile and Leon for 1518 to 1650. They elaborated three consumer baskets: one using the Phelps Brown and Hopkins (1956) weightings, also used by Martín Aceña (1992), and another two representing different levels of purchasing power. They compared the resulting inflation rates and their volatility, which turned out to be extremely high. Significantly, they rejected the existence of co-integration - common trends - between the indexes of New Castile and Old Castile for the 1518 - 1650 period. More recently, Drelichman (2005) constructs two baskets for traded and non-traded goods, based on Hamilton's prices, with the aim of proving how the influx of silver to Spain would have caused a "Dutch disease" process consisting of a high increase of prices and specialization in non-traded sectors and a decline in traded ones. As an indirect consequence, a rent seeking society would have strengthened institutions that obstructed Spanish economic growth in the subsequent century. The empirical base for this assertion is the estimation of a three regime Markov switching model for the real exchange rates between both 
sectors for New and Old Castile, and Valencia for the period 1531-1600. The regime of "Dutch disease" corresponds to a low state regime in mean and variance for the approximate period $1550-1580$.

This paper complements such approximations by dealing explicitly with the cyclical and convergence dynamics present in inflation rates. The main objective of this paper is to obtain inflation rates based on Hamilton's indexes in order to better understand the short and long-term variations (that is, cyclical and trend dynamics) affecting prices in the three centuries analysed. These rates revealed the existence of a cycle common to all four regions examined (Andalusia, New Castile, Old Castile and Valencia), and of an inflation rate convergence process. The inflation of the vellón ${ }^{1}$ that took place in the first half of the seventeenth century prevented inflation rates for New and Old Castile from converging with those of Valencia, which had been occurring throughout the sixteenth century. Following the success of Charles II's monetary reforms, this process resumed, resulting in full inflation rate convergence throughout the eighteenth century. Some important additional finding is the presence of a higher inflation rate in the first half of the sixteenth century compared with those of the second half and the seventeenth century in which the influx of silver reached its greater levels.

In order to obtain inflationary signals based on Hamilton's six fifty-year segments of prices for Old and New Castile, Andalusia and Valencia, a single price index is built for the entire 1501 to 1800 period in each of the four regions, allowing in this way calculations of segment-to-segment inflation rates. By basing our model on unobserved components it is possible to obtain a common variation component - common cycle for the four regions and also other long-term components - trends - in these price indexes. Increases in long-term components yielded an estimation of trend inflation that confirms the process of convergence between the four regions once monetary stability had been reached.

This paper has been organised as follows. Section 2 is a description of the econometric methodology used. Section 3 shows the price index time series for the entire sample period, obtained by estimating univariate models for each of Hamilton's indexes. This allows us to estimate missing observations, and to notice in the resulting indexes the existence of inflationary and deflationary periods common to all four regions. In section 4 , a model of the combined indexes yields a clear cyclical variation component common to all four inflation rates. The information supplied by this multivariate model enabled us to delimit inflationary and deflationary periods. Section 5 estimates trend components in the indexes obtained in section 4, confirming the existence of an inflation rate convergence process and the fulfilment, therefore, of the purchasing power parity condition (in growth rates). Conclusions are presented in section 6.

\section{Econometric methodology}

\footnotetext{
${ }^{1}$ The vellón (billon) is a based copper coin generally used as small change. Before 1602, it also contained a proportion of silver. The bibliography on the vellón and the monetary reforms affecting its face value and composition is very abundant. For introductory purposes, see, for example, Velde and Weber (2000).
} 
In this section, the models used in later sections are explained. The basic univariate model here employed is called cyclical trend (Cendejas et al. 2006). This is an unobserved component model in which the trend component results from the accumulation along time of the cyclical component and of a drift term containing the mean growth for the period. The univariate cyclical trend model is estimated for each price index in order to both eliminate base year changes and to obtain preliminary inflation signals. An analysis of the single base year indexes, and of their inflation signals, confirm the existence of characteristics shared by all four indexes; specifically, it is accurate to speak of cyclical synchrony. Secondly, the four time series of price indexes are combined, including this synchrony characteristic, into a single model by means of a multivariate unobserved component model with a common cyclical factor.

Both models are explained here in greater detail. The cyclical trend univariate model modifies the more common trend plus cycle decomposition used in macroeconomics (Harvey 1985; Watson 1986; Clark 1987; Nelson 1988). Trend plus cycle decomposition assumes a certain time series $y_{t}$ (most frequently, output) to be the sum of a trend and a cycle component, so that $y_{t}=T_{t}+C_{t}$. The cycle, then, causes $y_{t}$ to temporarily deviate from its trend level. This decomposition can be obtained by applying filters in the frequency domain or by means of smoothing algorithms. Nevertheless, ad hoc use of filters has been widely questioned because of the possibility of introducing information not actually present in the data (Harvey and Jaeger 1993; Cogley and Nason 1995; Murray 2003).

The main difference between the decomposition proposed here (cyclical trend) and trend plus cycle decomposition is that the former assumes that the trend component (non-stationary) accumulates the cyclical component (stationary) in addition to a mean trend growth included in the drift parameter. Specifically, the $y_{t}$ series is the sum of a trend (cyclical trend) and white noise,

$$
y_{t}=T_{t}+e_{t}
$$

where $e_{t} \sim$ iid $N\left(0, \sigma_{e}^{2}\right)$. The cyclical trend follows the model

$$
T_{t}=\mu+T_{t-1}+C_{t-1}
$$

where $\mu$ is the drift parameter, and $C_{t}$ the cyclical component. This follows an autoregressive representation

$$
\phi(L) C_{t}=\varepsilon_{t}
$$

with $\varepsilon_{t} \sim$ iid $N\left(0, \sigma_{\varepsilon}^{2}\right)$ and $\mathrm{E}\left(e_{t} \cdot \varepsilon_{s}\right)=0$ for each pair $(t, s)$. The roots of the $p$-th order autorregresive polynomial, $\phi(L)=1-\phi_{1} L-\phi_{2} L^{2}-\ldots-\phi_{p} L^{p}$, are assumed to be stationary. The state space representation of the model (1) allows the parameters (autoregressive, drift and variance parameters ${ }^{2}$ ) to be estimated based on maximum likelihood by using the Kalman filter, and to obtain the filtered, trend and cyclical components $T_{t \mid t}$ and $C_{t \mid t}$. The smoothed cyclical and trend components, $T_{t \mid T}$ and $C_{t \mid T}$, are obtained by conditioning on the entire sample by means of a fixed interval smoothing algorithm (Harvey 1989).

\footnotetext{
${ }^{2}$ Another possibility, that is followed here, is to estimate the noise variance ratio $n v r=\sigma_{\varepsilon}^{2} / \sigma_{e}^{2}$, see Young (1994). The importance of this parameter in obtaining the trend will be discussed in the section 5 .
} 
The multivariate modelling allows us to estimate the cyclical variation shared by all four price index series. This yields a common factor (common cycle) and variation components specific to each price index. The model used is the Stock and Watson $(1989,1991)$ multivariate model with a common factor that it is here modified to admit non-stationary series. Stock and Watson (1991) propose estimating a coincidental activity indicator constructed from monthly time series similar to those built by the U.S. Department of Commerce. To this end, they assume the cyclical component to be unobserved and common, so that each series is the sum of this common component and another specific component. Both the common and specific factors are modelled using an autoregressive structure. These authors use transformed stationary series (logarithmic differences) assumed to be non-cointegrated. Modelling can be done using the stationary transformation of the series, or by admitting non-stationary components, which allows long-term growth considerations, and from that, time series convergence analysis (Cendejas et al. 2006). Like the cyclical trend univariate model (1), the multivariate cyclical trend model with a common factor is represented and estimated in the state space.

As a result, it is assumed that

$$
y_{i, t}=T_{i, t}+e_{i, t}
$$

where the subscript $i=1, \ldots, m$ indicates the $i$-th series, $e_{i . t} \sim i i d N\left(0, \sigma_{e, i}^{2}\right)$ and $\mathrm{E}\left(e_{i, t}, e_{j, s}\right)=0$ for $i \neq j$ and each pair $(t, s)$. Each cyclical trend $T_{i, t}$ follows the model

$$
T_{t, i}=\mu_{i}+T_{i, t-1}+\gamma_{i} C_{t-1}+C_{i, t-1}
$$

where $\gamma_{\mathrm{i}}$ is the factor loading. Each trend has its own drift parameter $\mu_{i}$. The common cyclical component $C_{t}$ follows a stationary autoregressive process with variance equal to 1 to allow the identification of the model

$$
\phi(L) C_{t}=\varepsilon_{t}
$$

with $\varepsilon_{t} \sim$ iid $N(0,1)$ and $\mathrm{E}\left(e_{i, t} \cdot \varepsilon_{s}\right)=0$ for every $i$ and every pair $(t, s)$. The $p$-th order autoregressive polynomial, $\phi(L)=1-\phi_{1} L-\phi_{2} L^{2}-\ldots-\phi_{p} L^{p}$ is assumed to have stationary roots. The specific cyclical components $C_{i, t}$ are characterised as

$$
\psi_{i}(L) C_{i, t}=\varepsilon_{i, t}
$$

with $\varepsilon_{i, t} \sim$ iid $N\left(0, \sigma_{\varepsilon, i}^{2}\right)$ and $\mathrm{E}\left(\varepsilon_{i, t} \cdot \varepsilon_{j, s}\right)=0$ for $i \neq j$ and every pair $(t, s) ; \mathrm{E}\left(e_{i, t} \cdot \varepsilon_{j, s}\right)=0$ and $\mathrm{E}\left(\varepsilon_{t} \cdot \varepsilon_{i, s}\right)=0$ for every pair $(i, j)$ and $(t, s)$. The $p_{i}$-th order autoregressive polynomial $\psi_{i}(L)=1-\psi_{i, 1} L-\psi_{i, 2} L^{2}-\ldots-\psi_{i, p_{i}} L^{p_{i}}$ is assumed to have stationary roots.

In the two following sections, models (1) and (2) are estimated and analysed for Hamilton's price index series.

\section{Obtaining inflation rates using the univariate model}

In this section the univariate econometric analysis of Hamilton's price indexes for Andalusia, New Castile, Old Castile and Valencia is addressed. This model is required as a preliminary step and justifies a multivariate model with a common cyclical factor that will later be our reference model. 
If the indexes were taken in their original state, year on year inflation variations would be too abrupt, ranging from $-20 \%$ to $20 \%$ until 1550 and from $-10 \%$ to $10 \%$ from that year, and the changes of sign very frequent. This behaviour can be attributed to a great extent to the price of foodstuffs (particularly wheat), in the context, moreover, of a mainly farming economy. Another characteristics of the collected data that increases variability are the scarce number of prices available, especially in the mentioned first segment of the sample ${ }^{3}$, and the limited time and space sampling when compared to a present-day consumer price index. This facts do not imply that the original indexes contain uninformative noise nor discredit Hamilton's commendable effort. On the contrary, in spite of these data characteristics, unobserved component extraction techniques applied to the original indexes allow to obtain information on inflationary signals that would otherwise remain hidden. These signals will be useful for dating continuous periods of inflation or deflation and facilitate finding other correlated signals, specially of monetary type.

Using unobserved components in the construction of our model also allows us to cover observations missing at the start of the sample period in the Andalusian indexes (throughout much of the sixteenth century), and in those of Old Castile and Leon (until 1531), and to remove the base year changes introduced by Hamilton every 50 years. The accurate indexes not constructed by Hamilton for the years with missing observations are not obtained, nor the base year changes corrected as if the original information were available. The approach used covers these gaps and extends the dynamic characteristics of the sample where observations are available up to the point where they are missing. Therefore, both the interpolated observations in both cases mentioned and the estimated modifications are consistent with all the statistical information available. This is done using both univariate and multivariate modelling. A multivariate model allows us to use information from series that have observations for the entire period (New Castile and Valencia) to estimate observations missing in the other series (Andalusia and Old Castile and Leon), exploiting the common cyclical variation. Because of this, the multivariate model is more accurate, and preferable to univariate models, for estimating both missing observations and interventions due to base year changes, and therefore, for obtaining inflationary signals.

The results of the estimation of the cyclical trend model (1) are given in Table 1, while Fig. 1 and 2 show the original and modified index series respectively. Modification consists of interpolating missing observations and correcting the steps caused in the original series by the base year changes every 50 years. Fig. 3 shows the smoothed (i.e. full sample conditioned) trends of the modified indexes. Their variations, as a percentage, are called here inflationary signals (Fig. 4).

\footnotetext{
${ }^{3}$ The consumer goods considered and their temporal availability are detailed in Hamilton (1934, 1947) appendixes. In addition to the number of goods, to increase the number of available prices to calculate the average price of a good causes its variance to reduce, that is, the sample average is more precise.
} 
Table 1 Univariate cyclical trend model (1) estimations for price indexes. Period: 15011800

\begin{tabular}{|c|c|c|c|c|}
\hline & Andalusia & $\begin{array}{c}\text { New } \\
\text { Castile }\end{array}$ & $\begin{array}{c}\text { Old Castile } \\
\text { and Leon }\end{array}$ & Valencia \\
\hline $\begin{array}{c}\mu \\
\text { (drift parameters) }\end{array}$ & $\begin{array}{c}1.3341 \\
(0.2217)\end{array}$ & $\begin{array}{c}0.8432 \\
(0.2237)\end{array}$ & $\begin{array}{c}0.8281 \\
(0.2110)\end{array}$ & $\begin{array}{c}0.6047 \\
(0.1997)\end{array}$ \\
\hline$\phi_{1}$ & $\begin{array}{c}1.4663 \\
(0.0602)\end{array}$ & $\begin{array}{c}1.4467 \\
(0.0567)\end{array}$ & $\begin{array}{c}1.4689 \\
(0.0458)\end{array}$ & $\begin{array}{c}1.2915 \\
(0.0730)\end{array}$ \\
\hline $\begin{array}{c}\phi_{2} \\
\text { (autoregressive } \\
\text { parameters) }\end{array}$ & $\begin{array}{l}-0.6776 \\
(0.0610)\end{array}$ & $\begin{array}{l}-0.7141 \\
(0.0614)\end{array}$ & $\begin{array}{l}-0.7431 \\
(0.0497)\end{array}$ & $\begin{array}{l}-0.5860 \\
(0.0776)\end{array}$ \\
\hline$n v r^{-1}$ & $\begin{array}{l}26.1876 \\
(2.5572)\end{array}$ & $\begin{array}{l}27.6054 \\
(2.7369)\end{array}$ & $\begin{array}{l}18.4573 \\
(1.9421)\end{array}$ & $\begin{array}{c}9.1985 \\
(0.9507)\end{array}$ \\
\hline \multicolumn{5}{|l|}{$\begin{array}{l}\text { Interventions to } \\
\text { correct for base } \\
\text { year changes in: }\end{array}$} \\
\hline 1551 & $\begin{array}{l}88.5306 \\
(6.8976)\end{array}$ & $\begin{array}{l}85.7623 \\
(6.8341)\end{array}$ & $\begin{array}{l}60.1709 \\
(6.0644)\end{array}$ & $\begin{array}{l}50.2990 \\
(4.4643)\end{array}$ \\
\hline 1601 & $\begin{array}{l}50.7267 \\
(6.8471)\end{array}$ & $\begin{array}{l}51.3641 \\
(6.7302)\end{array}$ & $\begin{array}{l}43.7541 \\
(5.9618)\end{array}$ & $\begin{array}{l}36.6330 \\
(4.4646)\end{array}$ \\
\hline 1651 & $\begin{array}{l}58.0000 \\
(6.8500)\end{array}$ & $\begin{array}{l}51.1791 \\
(6.6949)\end{array}$ & $\begin{array}{l}52.5843 \\
(5.9228)\end{array}$ & $\begin{array}{l}-8.6361 \\
(4.4767)\end{array}$ \\
\hline 1701 & $\begin{array}{l}-44.5080 \\
(6.8089)\end{array}$ & $\begin{array}{l}-43.0508 \\
(6.6796)\end{array}$ & $\begin{array}{l}-30.2397 \\
(5.9264)\end{array}$ & $\begin{array}{l}-2.8637 \\
(4.4996)\end{array}$ \\
\hline 1751 & $\begin{array}{l}24.1412 \\
(6.8215)\end{array}$ & $\begin{array}{l}29.4698 \\
(6.8056)\end{array}$ & $\begin{array}{l}32.7051 \\
(5.9496)\end{array}$ & $\begin{array}{l}27.2210 \\
(4.4506)\end{array}$ \\
\hline
\end{tabular}

Standard errors are shown in brackets

Fig. 1 Hamilton's original indexes. 1501=100

Fig. 2 Hamilton's indexes modified to correct for missing observations and base year changes. $1501=100$

Fig. 3 Smoothed trends of Hamilton's modified price indexes. 1501=100

Fig. 4 Inflationary signals calculated from the smoothed trends of the cyclical trend model (1) (unit: percentage variation)

In Table 1, the drift parameters $\mu$ measure the average trend growth along the period. A comparison of all four regions reveals greater inflation in Andalusia; this is confirmed 
in Fig. 2 and 3, which show that this is indeed the case up to around 1680. The autoregressive parameters $\left(\phi_{1}\right.$ and $\left.\phi_{2}\right)$ show the relatively smooth systematic variation of estimated inflationary signals. Here, the statistical equality in Andalusia and New and Old Castile is important. New and Old Castile also show the same drift parameters; this indicates equal long-term growth. The variance ratio ${ }^{4}$ is clearly lower in Valencia, indicating less variability in the original index, that is, less relative weight in erratic variations (also see Fig. 2). Estimated intervention parameters allow us, as mentioned above, to correct for the steps, which would otherwise be evident due to base year changes every 50 years. Calculating growth rates based on smoothed index trends (Fig. 4) allows us to verify their significant synchrony and propose an estimation that includes a common variation component, that is, a common cyclical factor.

Table 2 Comparison of accumulated inflation rates $\left(^{*}\right)$ (univariate model)

\begin{tabular}{ccccccccc} 
& \multicolumn{2}{c}{ Andalusia } & \multicolumn{2}{c}{ New Castile } & \multicolumn{2}{c}{ Old Castile and } & \multicolumn{2}{c}{ Valencia } \\
\cline { 2 - 9 } & Index & Signal & Index & Signal & Index & Signal & Index & Signal \\
\hline $1501-1551$ & 97.4 & 93.3 & 79.2 & 87.4 & 67.2 & 56.6 & 55.3 & 44.5 \\
$1551-1601$ & 39.4 & 36.0 & 42.2 & 35.5 & 38.9 & 40.8 & 45.5 & 44.5 \\
$1601-1651$ & 24.3 & 21.4 & 15.3 & 17.6 & 13.9 & 15.3 & 1.6 & 3.8 \\
$1651-1701$ & -13.3 & -8.0 & -2.0 & -2.3 & -1.6 & 0.4 & -8.9 & -9.0 \\
$1701-1751$ & 3.8 & 0.2 & 2.8 & 3.0 & 6.9 & 4.8 & 3.9 & 3.6 \\
$1751-1800$ & 25.4 & 29.9 & 18.7 & 24.1 & 27.6 & 28.6 & 23.4 & 32.4 \\
Total: 1501- & 287.3 & 280.0 & 250.5 & 266.8 & 249.3 & 239.8 & 166.7 & 169.0 \\
1800 & & & & & & &
\end{tabular}

(*) Accumulated inflation rates have been obtained from both the modified indexes and their smoothed trends. Both estimations come from the univariate cyclical trend model (1).

The accumulated inflation rates every 50 years and for the entire period are shown in Table 2. They have been calculated from the modified indexes and the smoothed trends previously obtained. Both the sixteenth century and the first half of the seventeenth century clearly register a higher rate of inflation than the rest of the period. Inflation falls off as 1650 approaches, in spite of the fact that the inflation of the vellón occurred in the first half of this century. As a whole, the second half of the seventeenth century is deflationary, and the effects of the monetary reforms brought in from 1680-86 are clear (Font 2004, 2005). While prices remained stable during the first half of the eighteenth century, the second half was again dominated by inflation, albeit below sixteenth century rates, which is when most of the price increases for the entire period occur. This fact prompted Nadal (1959) to reject Hamilton's hypothesis that the arrival of silver from America was the main cause of the "price revolution", as large cargoes of this metal arrived in Spain during the second half of the sixteenth century. However, the possibility of a monetary cause cannot be ruled out (Munro 2007) because the supply of money had already increased due to copper and silver mining in southern Germany and Central Europe, reaching its peak in the period from 1460 to 1540.

\footnotetext{
${ }^{4}$ The opposite $n v r^{-1}$ has been estimated due to its numerical magnitude.
} 
By regions, Valencia is clearly less inflationary. Fig. 2 also shows the absence of the important fluctuations affecting other regions throughout the seventeenth century. In Table 2 it can be seen that the deflationary period (second half of the seventeenth century) is more pronounced in Andalusia. In this table, differences resulting from comparing variations in the modified indexes with variations in their smoothed trends are due to great fluctuations in the original indexes and the large number of sharp variations that affect calculations of mean rates. These are not found in the smoothed trends. Nevertheless, the by-period description does not change because of considering either the modified indexes or their smoothed trends.

It is evident that the inflation figures in Table 2 suggest much lower average annual inflation rates compared to those experienced by twentieth century fiduciary monetary systems, where deflation, moreover, has been a rare phenomenon ${ }^{5}$. A priori, a fiduciary monetary system (plus the monopoly to issue money) must be more inflationary than other metallic cash-based systems because of the ease with which the money supply can be increased in the former. The characteristics in the original Hamilton's indexes mentioned previously could also affect these figures, although to a lesser extent. In spite of this, it seems clear from the foregoing graphs that these indexes contain valuable information, and that index-based price variations, or the inflationary signals that reduce the original, highly fluctuating, year-on-year figures, are extremely useful.

\section{Common cyclical variation in inflation rates}

The convergence of inflationary signals allows us to group indexes together in the multivariate model. In this model, which includes the foregoing univariate models, the hypothesis of price variation assimilation in all four regions, that is, the existence of a common inflation cycle can be tested. Table 3 shows the results of the estimation of the multivariate model with a common cyclical factor.

The existence of common variations in the original indexes can be verified by testing the significance of the factor loading parameters. These show the relationship between the common cyclical factor and the cyclical variation of each index. If these are significant, it indicates that the cyclical variation of each series is mainly the result of the cyclical variation common to all. In Table 3 it can be seen that factor loadings are clearly statistically significant, that is, it can be said that all four regions share a common inflationary variation. Less factor loading in the Valencia indexes indicates greater price stability, that is, the same variations are expressed with smaller amplitude ${ }^{6}$. The factor loadings for both Old and New Castile and Andalusia are statistically similar, as are the drift parameters for both Old and New Castile, which measure the average growth of the trends. Therefore, prices have risen, expressing the same medium term

\footnotetext{
${ }^{5}$ The average annual rate of inflation between 1501 and 1800 was $0.5 \%$ in Andalusia, $0.4 \%$ in New and Old Castile, and $0.3 \%$ in Valencia. In the first half of the sixteenth century, the most inflationary period, average annual inflation rates stood at $1.4 \%, 1.2 \%, 1.0 \%$ and $0.9 \%$ respectively. We agree with the remarks made by Martín Aceña (1992) when he pointed out that it is fair to speak of a "price revolution" not because of the amount prices increased, but because the trend lasted for around 150 years.

${ }^{6}$ The error term of the common cyclical variation has a standard variance of 1 , so that differences in cyclical amplitude are seen in factor loadings.
} 
variation in all four regions, though in the long-term, prices increased more in Andalusia, followed by Old and New Castile and Valencia.

Table 3 Multivariate model (2) with common cyclical factors for price indexes. Period: $1501-1800$

\begin{tabular}{|c|c|c|c|c|}
\hline & Andalusia & $\begin{array}{c}\text { New } \\
\text { Castile }\end{array}$ & $\begin{array}{l}\text { Old Castile } \\
\text { and Leon }\end{array}$ & Valencia \\
\hline $\begin{array}{c}\gamma_{\mathrm{i}} \\
\text { (factor loadings) }\end{array}$ & $\begin{array}{c}2.5095 \\
(0.3322)\end{array}$ & $\begin{array}{c}2.2903 \\
(0.3126)\end{array}$ & $\begin{array}{l}2.5272 \\
(0.3426)\end{array}$ & $\begin{array}{c}0.9289 \\
(0.1690)\end{array}$ \\
\hline $\begin{array}{c}\mu_{\mathrm{i}} \\
\text { (drift parameters) }\end{array}$ & $\begin{array}{l}1.4040 \\
(0.2404)\end{array}$ & $\begin{array}{c}1.1526 \\
(0.2359)\end{array}$ & $\begin{array}{c}1.0803 \\
(0.2712)\end{array}$ & $\begin{array}{c}0.6618 \\
(0.2273)\end{array}$ \\
\hline $\begin{array}{c}\phi_{1} \text { y } \phi_{2} \\
\text { (common cycle } \\
\text { autoregressive } \\
\text { parameters) }\end{array}$ & \multicolumn{4}{|c|}{$\begin{array}{cc}0.9308 & (0.1215) \\
-0.4810 & (0.0907)\end{array}$} \\
\hline $\begin{array}{c}\psi_{\mathrm{i}} \\
\text { (specific variation } \\
\text { autoregressive } \\
\text { parameters) }\end{array}$ & n.s. & $\begin{array}{c}0.1244 \\
(0.2718)\end{array}$ & $\begin{array}{c}0.4759 \\
(0.1067)\end{array}$ & $\begin{array}{c}0.7165 \\
(0.0472)\end{array}$ \\
\hline$n v r_{i}^{-1}$ & $\begin{array}{l}26.6748 \\
(2.9517)\end{array}$ & $\begin{array}{l}22.4525 \\
(2.2980)\end{array}$ & $\begin{array}{l}12.8354 \\
(1.5708)\end{array}$ & $\begin{array}{c}9.7013 \\
(1.0141)\end{array}$ \\
\hline \multicolumn{5}{|l|}{$\begin{array}{l}\text { Interventions to } \\
\text { correct for base } \\
\text { year changes in: }\end{array}$} \\
\hline 1551 & $\begin{array}{l}95.1692 \\
(5.6724)\end{array}$ & $\begin{array}{l}84.4126 \\
(5.1693)\end{array}$ & $\begin{array}{l}60.9650 \\
(5.2039)\end{array}$ & $\begin{array}{l}49.3747 \\
(4.0269)\end{array}$ \\
\hline 1601 & $\begin{array}{l}43.3675 \\
(5.8728)\end{array}$ & $\begin{array}{l}47.1715 \\
(5.5077)\end{array}$ & $\begin{array}{l}40.6291 \\
(5.6069)\end{array}$ & $\begin{array}{l}33.5362 \\
(4.0915)\end{array}$ \\
\hline 1651 & $\begin{array}{l}58.5713 \\
(5.8951)\end{array}$ & $\begin{array}{l}53.2705 \\
(5.4975)\end{array}$ & $\begin{array}{l}52.6494 \\
(5.5785)\end{array}$ & $\begin{array}{l}-8.2309 \\
(4.1114)\end{array}$ \\
\hline 1701 & $\begin{array}{l}-40.3093 \\
(5.8973)\end{array}$ & $\begin{array}{l}-38.6930 \\
(5.4946)\end{array}$ & $\begin{array}{l}-32.3803 \\
(5.6131)\end{array}$ & $\begin{array}{l}-2.1537 \\
(4.0895)\end{array}$ \\
\hline 1751 & $\begin{array}{l}27.3378 \\
(5.8877)\end{array}$ & $\begin{array}{l}25.0375 \\
(5.4907)\end{array}$ & $\begin{array}{l}30.6623 \\
(5.5845)\end{array}$ & $\begin{array}{l}27.7010 \\
(4.0893)\end{array}$ \\
\hline
\end{tabular}

Standard errors are shown in brackets

n.s.: statistically not significant

In addition to the foregoing, it has also been shown that three of the indexes (the exception being Andalusia) also have specific cyclical variations. Estimation of not null specific variation components prevents the common cyclical factor model from being reduced to a common trend model, that is, there is no a common trend component for the entire sample period (Cendejas et al. 2006). Graphically, it would be an indication that the slopes were similar, which only occurs in the eighteenth century. Estimations of 
the remaining parameters ( $n v r^{-1}$ and interventions) are very similar to those obtained from previous univariate models.

Another aim of the multivariate model, in addition to testing the existence of shared inflationary variations, was to use the information in the series to correct for missing observations in some indexes. In the case of Andalusia, and to a lesser extent, Old Castile, there are many missing observations. Information shared by the original series has enabled us to interpolate and obtain estimations of these observations using information not available in univariate modelling. Although changes in the smoothed trends of the multivariate model, and therefore in inflationary signals, are not dramatic when compared to those obtained from univariate models, they are relevant to a certain extent. Because of this, accumulated mid-century rates have been recalculated in Table 4. In this Table, accumulated inflation rates confirm Andalusia as the most inflationary region, followed by New Castile, Old Castile and Valencia. Andalusia continues to be the region with greatest deflation in the second half of the seventeenth century, and inter-regional inflation differences are irrelevant in the eighteenth century.

Table 4 Comparison of accumulated inflation rates $(*)$ (multivariate model)

\begin{tabular}{ccccccccc} 
& \multicolumn{2}{c}{ Andalusia } & \multicolumn{2}{c}{ New Castile } & \multicolumn{2}{c}{ Old Castile and } & \multicolumn{2}{c}{ Valencia } \\
\cline { 2 - 9 } & Index & Signal & Index & Signal & Index & Signal & Index & Signal \\
\hline $1501-1551$ & 103.0 & 102.8 & 77.2 & 78.6 & 57.9 & 57.4 & 40.7 & 41.3 \\
$1551-1601$ & 33.7 & 33.3 & 38.7 & 37.2 & 40.0 & 40.4 & 47.4 & 45.3 \\
$1601-1651$ & 22.8 & 19.1 & 17.1 & 18.8 & 15.3 & 16.1 & 3.1 & 5.0 \\
$1651-1701$ & -9.7 & -6.1 & -0.1 & -2.2 & -1.3 & -0.7 & -6.8 & -8.4 \\
$1701-1751$ & 3.6 & 1.7 & 0.5 & 2.1 & 5.6 & 3.7 & 3.7 & 4.9 \\
$1751-1800$ & 27.1 & 26.2 & 20.3 & 21.2 & 27.2 & 26.7 & 30.7 & 35.2 \\
Total: $1501-$ & 293.1 & 285.6 & 250.2 & 249.9 & 235.4 & 232.2 & 168.1 & 178.6 \\
1800 & 2900
\end{tabular}

(*) Accumulated inflation rates have been obtained from both the modified indexes and their smoothed trends. Both estimations come from the multivariate model with common cyclical factor (2).

By comparing the inflationary signals obtained from the univariate and multivariate models, it can be noted that the smoothed trends obtained from the multivariate model have been slightly noisier than those obtained from the univariate models (Fig. 5). This, to a certain extent, gives more positive and negative variations and reduces the duration of inflationary or deflationary periods. Nevertheless, we have checked that the dating does not experience a substantial change. Periods of significant inflation or deflation remain the same, and geographic synchrony remains extensive.

Fig. 5 Inflationary signals calculated from the smoothed trends of the multivariate model with common cyclical factor (2) (unit: percentage variation) 
Obtaining inflationary signals based on smoothed trend variations allows us to assign a more detailed dating than those obtained from Table 4. A number of years can be classified as being predominantly inflationary or deflationary by basing on the positive or negative sign of the variation. It must be remembered that the smoothed indexes (inflationary signal) avoid the frequent changes in sign occurring nearly every year in the original price index figures. These are a result of the original variability and not necessarily due to a change from a relatively long inflationary period to another deflationary one. Table 5 shows the dates obtained from the inflationary signals from the multivariate model. The criteria followed for classifying periods has been to consider periods in which the smoothed trend decreases as deflationary, with inflationary periods being those where the opposite is true. If the change from positive to negative has lasted only one year, it has not been taken into consideration. That is, the sign to continue for at least two years ${ }^{7}$ is required.

Table 5 Dating of inflationary and deflationary periods $(*)$ according to the estimated inflationary signals based on the multivariate cyclical trend model (2)

\begin{tabular}{|c|c|c|c|c|c|c|c|}
\hline \multicolumn{2}{|c|}{ Andalusia } & \multicolumn{2}{|c|}{ New Castile } & \multicolumn{2}{|c|}{ Old Castile and Leon } & \multicolumn{2}{|c|}{ Valencia } \\
\hline $\begin{array}{l}\text { Inflationary } \\
\text { periods }\end{array}$ & $\begin{array}{l}\text { Deflationary } \\
\text { periods }\end{array}$ & $\begin{array}{l}\text { Inflationary } \\
\text { periods }\end{array}$ & $\begin{array}{l}\text { Deflationary } \\
\text { periods }\end{array}$ & $\begin{array}{l}\text { Inflationary } \\
\text { periods }\end{array}$ & $\begin{array}{l}\text { Deflationary } \\
\text { periods }\end{array}$ & $\begin{array}{l}\text { Inflationary } \\
\text { periods }\end{array}$ & $\begin{array}{l}\text { Deflationary } \\
\text { periods }\end{array}$ \\
\hline $1501-1506$ & & $1501-1506$ & & 1501-1506 & & $1501-1506$ & \\
\hline & $1507-1510$ & & $1507-1510$ & & $1507-1512$ & & $1507-1509$ \\
\hline & & $1511-1514$ & & $1513-1514$ & $1515-1516$ & $1510-1523$ & $1524-1526$ \\
\hline $1511-1531$ & & & & $1517-1523$ & & & \\
\hline & & $1517-1531$ & & & $1524-1525$ & $1527-1531$ & \\
\hline & 1532-1534 & & 1532-1535 & $1526-1531$ & 1532-1535 & & $1532-1535$ \\
\hline $1535-1550$ & & $1536-1551$ & & $1536-1543$ & $1544-1545$ & & \\
\hline & & & & $1546-1550$ & & & \\
\hline & $1551-1553$ & & $1552-1553$ & & $1551-1552$ & $1536-1563$ & \\
\hline $1554-1565$ & & & & 1553-1558 & $1559-1560$ & & \\
\hline & & $1554-1574$ & & $1561-1565$ & & & \\
\hline & $1566-1568$ & & & & $1566-1569$ & & $1564-1565$ \\
\hline $1569-1574$ & $1575-1577$ & & $1575-1577$ & $1570-1574$ & $1575-1577$ & $1566-1592$ & \\
\hline & & $1578-1585$ & & $1578-1579$ & & & \\
\hline $1578-1585$ & & & & & $1580-1581$ & & $1593-1595$ \\
\hline & $1586-1588$ & & $1586-1588$ & $1582-1585$ & $1586-1588$ & & \\
\hline $1589-1592$ & & $1589-1592$ & & $1589-1592$ & & & \\
\hline & $1593-1594$ & & $1593-1595$ & & $1593-1594$ & $1595-1600$ & \\
\hline $1595-1600$ & & $1596-1600$ & & $1595-1600$ & & & \\
\hline $1603-1605$ & $1601-1602$ & $1603-1605$ & $1601-1602$ & 1603-1605 & 1601-1602 & & \\
\hline & $1606-1612$ & & $1606-1612$ & & $1606-1612$ & & $1601-1609$ \\
\hline $1613-1617$ & & $1613-1617$ & & $1613-1617$ & & $1610-1617$ & \\
\hline $1620-1628$ & 1618-1619 & $1620-1628$ & 1618-1619 & $1621-1628$ & $1618-1620$ & $1624-1637$ & $1618-1623$ \\
\hline & $1629-1634$ & & $1629-1635$ & & $1629-1635$ & & $1638-1640$ \\
\hline $1635-1642$ & & $1636-1642$ & & $1636-1642$ & & $1641-1642$ & \\
\hline
\end{tabular}

\footnotetext{
${ }^{7}$ This dating rule is commonly used in business cycle analysis, albeit applied to quarterly GDP observations.
} 


\begin{tabular}{|c|c|c|c|c|c|c|c|}
\hline \multirow[b]{2}{*}{1646} & $1643-1645$ & \multirow[b]{2}{*}{$1646-1652$} & $1643-1645$ & & \multicolumn{2}{|l|}{$1643-1645$} & $1643-1645$ \\
\hline & & & & $1646-1652$ & $1653-1657$ & $1646-1651$ & $1652-1662$ \\
\hline $1658-1667$ & $1668-1673$ & $1658-1668$ & 1669-1673 & $1658-1668$ & 1669-1673 & $1663-1665$ & $1666-1674$ \\
\hline $1674-1678$ & & $1674-1678$ & $1679-1688$ & $1674-1678$ & & $1675-1678$ & $1679-1682$ \\
\hline $1689-1690$ & $1691-1692$ & 1689-1695 & & 1688-1695 & & $1683-1584$ & $1585-1689$ \\
\hline $1698-1703$ & 1696-1697 & $1698-1703$ & $1696-1697$ & 1698-1704 & $1696-1697$ & $1690-1710$ & \\
\hline $1708-1710$ & $1704-1707$ & $1707-1710$ & $1704-1706$ & $1707-1710$ & 1705-1706 & & \\
\hline $1722-1728$ & 1711-1721 & $1722-1727$ & 1711-1721 & $1722-1728$ & $\begin{array}{l}\text { 1711-1721 } \\
\text { 1729-1731 }\end{array}$ & $1722-1735$ & 1711-1721 \\
\hline $\begin{array}{l}1732-1735 \\
1738-1741\end{array}$ & $\begin{array}{l}1729-1731 \\
\mathbf{1 7 3 6 - 1 7 3 7}\end{array}$ & $1732-1741$ & $1728-1731$ & $1732-1741$ & $1729-1731$ & $1738-1741$ & $1736-1737$ \\
\hline $1746-1755$ & 1742-1745 & $1746-1754$ & 1742-1745 & $1746-1754$ & $\begin{array}{l}1742-1745 \\
1755-1759\end{array}$ & $1746-1755$ & $\begin{array}{l}1742-1745 \\
1756-1761\end{array}$ \\
\hline $1760-1766$ & $1767-1768$ & $1761-1766$ & $1767-1770$ & $\begin{array}{l}1760-1765 \\
1770-1772\end{array}$ & 1766-1769 & $1762-1776$ & \\
\hline $1669-1798$ & & $1771-1798$ & & $1777-1798$ & $1773-1776$ & $1779-1798$ & $1777-1778$ \\
\hline & $1799-1800$ & & $1799-1800$ & & $1799-1800$ & & $1799-1800$ \\
\hline
\end{tabular}

(*) In bold: particularly important deflationary periods.

Table 5 shows the important regional synchrony of inflationary and deflationary periods as seen in Fig. 5. Although the dates do not coincide exactly, the synchrony hypothesis is further confirmed by the fact that a deflationary episode in a particular region, for example, while not necessarily linked to deflation in another, could have been linked to inflation falling off in that region. Based on Table 5 and Fig. 5, it is important to note the clear and significant synchrony of Valencia with the other three regions, in spite of its idiosyncratic evolution.

\section{Long run convergence of inflation rates and a monetary explanation}

The analysis described in the foregoing section confirms the presence of common inflationary variations in all four regions. It should be borne in mind that common inflationary variations did not result in a common long-term variation in the sixteenth and seventeenth centuries. Indeed, relevant specific characteristics have been found such as higher inflation in Andalusia and New Castile in the first half of the sixteenth century, greater deflation in Andalusia in the second half of the seventeenth century, and sharp inflationary and deflationary fluctuations in the Crown of Castile that are not found in Valencia, where inflation, moreover, has generally been lower.

Moreover, from the dating of Table 5 and the previous graphs, it should clearly pinpoint a fundamental break point in 1680, when the drop in prices was most pronounced. This price decrease follows an important increase around 1660, neither of which is as 
pronounced in Valencia, where the deflation of the second half of the seventeenth century developed more gradually. Neither does Valencia experience such an abrupt rise in prices as that registered in the other three regions during the sixteenth century. In fact, specific variation of Valencia, with less volatile dates, is concentrated in the seventeenth century. From the start of the seventeenth century, and up to the monetary reform of 1680, fluctuations in the indexes for New and Old Castile increase, but the same is not true for Valencia. Later, these fluctuations subside, and all four regions share both short and long-term growth along the eighteenth century.

With regard to the increasing trend in prices, Hamilton and others attribute inflation to the arrival of metals from America in the sixteenth and seventeenth centuries. The arrival of these shipments, the minting and issuance of new coins, coupled with the short-sighted monetary policies introduced at the beginning of the seventeenth century, were mainly responsible for inflation. Nevertheless, the connection between the quantity of precious metals received and the evolution of prices is far from straightforward, while the inflationary and deflationary effects of some of the monetary reforms implemented can be seen more clearly.

It is shown here how regional differences in long-term inflation rates gradually disappeared, giving way to a process of inflation rate convergence according to purchasing power parity in relative terms ${ }^{8}$. The obstacles to achieving this convergence derived primarily from the existence of different financial and monetary institutions in the regions under the Crown of Castile and in the Kingdom of Valencia. Ruiz Martín (1997) places the cause of the different inflationary behaviour in Castile and Valencia in the different attitudes towards the vellón. He argues that the system of the cambios prevailing in Valencia kept silver into circulation by avoiding massive copper receipts from Castile as compensation in financial transactions. On the contrary, in the Kingdoms of Castile and in spite of some prohibitions (until 1552 and from 1560 to 1566) the silver was massively exported (sacas) as payments for imports and credits, and for financing the Imperial wars in Europe. The paradoxical shortage of silver in Castile favoured the minting of copper as substitute in small changes and, simultaneously, as an important source of seignorage revenues for the Crown. The distorting interactions between fiscal needs and monetary policy (Álvarez 1997, 2001) help to understand this paradox and the absence of a simple parallelism between the evolution of inflation and silver remittances.

In fact, the Castilian monetary system was greatly distorted by indirect taxation in the form of seignorage and inflation (Font 2004, 2005, 2008; García de Paso 2000, 2003). Once these constraints were removed, convergence between Castilian inflation and that of Valencia became a reality. The other obstacle, limited to the first half of the sixteenth century, is the proximity of Andalusia to the centre of trade with America. From 1550, it is fair to speak of a convergence of inflation rates within the three Castilian regions (see Fig. 6).

Fig. 6 Trend inflation rates (unit: percentage variation)

\footnotetext{
${ }^{8} \mathrm{~A}$ reference to inter-regional price levels in the same currency during a same base year is needed in order to ascertain whether purchasing power parity in absolute terms had been achieved. This reference could be obtained from the detailed information supplied by Hamilton but exceeds the objectives of this paper.
} 
To support this thesis, trend component estimations have been made for the indexes obtained in the preceding section. To do this, the cyclical trend model (1) for each of the four modified indexes was estimated, and a $n v r^{-1}=1000$ parameter was imposed. By imposing this parameter, instead of estimating the model without parameter restrictions, the variation included in the trend can be regulated. The value used implies that fluctuations of period exceeding 35 years will remain in the trend, although slightly shorter fluctuations will appear when taking differences on this trend to calculate longterm inflation rates ${ }^{9}$.

Fig. 6 shows how, in the three regions included in the Crown of Castile, inflation slows down in the sixteenth century, is relatively stable in the first half of the seventeenth century, is reduced almost to the point of deflation with the 1680-86 reforms, and increases throughout the eighteenth century, with a brief deflationary period (1711-21). The same is true for Valencia, with the exception of the seventeenth century. After the monetary reforms, inflationary trend in Valencia follow those of the remaining regions. As can be seen from the magnitudes in Fig. 6, the first half of the seventeenth century is on average less inflationary than the sixteenth century. It is important to remember that long-term variations are being analysed here, and that the monetary instability characteristic of the period consisted of a series of both inflationary and deflationary measures that resulted in extremely variable prices with minor consequences in the long-term. Consequently the aforementioned process of substitution of silver by copper was far from being perfect and the "copper driven" monetary growth of the seventeenth century seems to have been lower and more instable than of the "silver driven" of the sixteenth century. This behaviour throws more light on the term inflation of the vellon, as this period is called, being more suitable, instead, to speak of instability of the vellón.

This dynamic is confirmed in the dispersion (standard deviation) of inflation trends ${ }^{10}$ observed in Fig. 7. The continuous vertical lines show the dates that potentially inflationary monetary measures affecting the vellón were introduced (debasement and restamping to a higher value). The dotted lines show deflationary measures (Font 2005, pp. 338 to $340^{11}$ ). It can be seen that the dispersion of the Castilian regions compared to Valencia increases, above all, with inflationary measures that depreciated the vellon, and fall off when the opposite is true. It should be borne in mind that Hamilton's indexes are based on prices in maravedies ${ }^{12}$. As retail payments were made in vellón coins, increasing the latter's face value (restamping), the most common inflationary measure, reduced the purchasing power of the coin, resulting almost immediately in price increases. The opposite was true when the coin was restamped to a lower value (García de Paso 2002). Adding Valencia to dispersion calculations has no effect after approximately the first twenty years of the eighteenth century, thus confirming inflation

\footnotetext{
${ }^{9}$ The relationship between different $n v r^{-1}$ parameter values and the period of oscillations included in the trend are obtained from the spectral characteristic of the filter. See, for example Harvey (2008).

${ }^{10}$ It can also be observed the limited magnitude of the dispersion of these long-term rates, which do not exceed one percentage point. This fact again allows us to show the differences between a metallic cash-based monetary system and a fiduciary one.

${ }^{11}$ Inflationary measures were adopted in the years 1532, 1596, 1597, 1602, 1603, 1636, 1641, $1642,1643,1652,1654,1658$ and 1659; and deflationary measures in the years 1566, 1628, $1651,1660,1664,1680$ and 1684.

${ }^{12}$ A Castilian unit of account whose metallic counterpart was abandoned before the period here analysed.
} 
rate convergence. It is important to note that the greatest dispersion does not occur at the end of the sixteenth century, when the first pure copper vellón coin was minted, but around 1636, when the coin was restamped to three times its value for the first time.

Fig. 7 Standard deviation of trend inflation

\section{Conclusions}

The econometric treatment applied to Hamilton's price indexes has enabled us to obtain relatively smooth inflationary signals for each of the four Spanish regions analysed. These signals smooth out the sharp variations in inflation rates present in the original indexes, and allow us to date prevailing periods of inflation and deflation. The synchrony of these periods has enabled us to prove the existence of a common cyclical factor in inflation rates. Other relevant specific characteristics have been found such as higher inflation in Andalusia and New Castile in the first half of the sixteenth century, greater deflation in Andalusia in the second half of the seventeenth century, and sharp inflationary and deflationary fluctuations in the Crown of Castile that are not found in Valencia, where inflation, moreover, has generally been lower. The predominance of the vellón in small change and the concentration of the influx of silver in the second half of the sixteenth century and the seventeenth century, complicate to reach simple conclusions on the monetary origin of inflation based on precious metals, but, on the contrary, would not deny a monetary origin based on copper coin and fiscal distortions.

When seen from the long-term, a gradual convergence of inflation rates becomes clear. This process was interrupted during much of the seventeenth century, and restarted following the monetary reforms introduced by Charles II. These results prove the existence of effective monetary integration between the Castilian regions, and also between these and Valencia, once the disturbances, caused by monetary policies evident throughout the seventeenth century, diminished. Monetary instability in this century is commonly known as inflation of the vellón and, really, consisted of a series of both inflationary and deflationary measures that resulted in extremely variable prices. This fact and the lower average inflation rates, compared with those of the sixteenth century, it would make more appropriate to speak of "instability of the vellón". After this episode and especially along the eighteenth century, the purchasing power parity condition in inflation rates is fulfilled.

Acknowledgements The authors would like to thank the Instituto de Investigaciones Económicas y Sociales "Francisco de Vitoria" for the grant received for this project from the 2nd and 3rd call for proposals for research projects. The authors would also like to thank Carlos Álvarez Nogal, Félix Fernando Muñoz Pérez, Pedro Schwartz Girón and Pedro Tedde de Lorca for their comments on this work and their help in improving this paper.

\section{References}

Álvarez Nogal C (1997) Los banqueros de Felipe IV y los metales preciosos americanos (1621-1665). Estudios de Historia Económica, Banco de España, Madrid 
Álvarez Nogal C (2001) Los problemas del vellón en el siglo XVII. ¿Se consiguió abaratar la negociación del crédito imponiendo precios máximos a la plata?. Revista de Historia Económica XIX: 17-37

Cendejas JL, Hoyo J, Llorente G, Monjas M, Rivero C (2006) Ciclo económico y convergencia real en la Unión Europea. Análisis de los PIB per cápita en la UE15. WP 10/06, BBVA Foundation, Madrid

Clark PK (1987) The cyclical component of U.S. Economic Activity. The Quarterly Journal of Economics 102: 797-814

Cogley T, Nason JM (1995) Effects of the Hodrick-Prescott filter on trend and difference stationary time series. Implications for business cycle research. Journal of Economic Dynamics and Control 19: 253-278

Drelichman M (2005) The Curse of Moctezuma: American Silver and the Dutch Disease. Explorations in Economic History 42: 349-380

Font de Villanueva C (2004) Pensamiento monetario y reforma económica en la Castilla de Carlos II: la estabilización de 1680-1686. PhD Dissertation, Universidad Autónoma de Madrid

Font de Villanueva C (2005) Política monetaria y política fiscal en Castilla en el siglo XVII: un siglo de inestabilidades. Revista de Historia Económica 1: 329-348

Font de Villanueva C (2008) La estabilización monetaria de 1680-1686. Pensamiento y política económica. Estudios de Historia Económica, Banco de España, Madrid

García de Paso JI (1999) La economía monetaria del Padre Juan de Mariana. Moneda y Crédito 209: 13-44

García de Paso JI (2000) La estabilización monetaria en Castilla bajo Carlos II. Revista de Historia Económica XVIII: 49-77

García de Paso JI (2002) The 1628 castilian crydown: a test of competing theories of the price level. Hacienda Pública Española 163: 71-91

García de Paso JI (2003) La política monetaria castellana de los siglos XVI y XVII. In: Valera M, Durán JJ (ed) La moneda en Europa. De Carlos V al euro. Pirámide, Madrid, pp 101-136

González MJ, Hoyo J (1983) Dinero y precios en la España del siglo XVI. Una confirmación de la tesis de Hamilton. Moneda y Crédito 166: 15-46

Hamilton EJ (1929) American treasure and the rise of capitalism, 1500-1700. Economica 27: 338-357

Hamilton EJ (1934) American treasure and the price revolution in Spain, 1501-1650. Octagon Books, New York. Spanish translation of A. Abad (1975), Ariel, Barcelona

Hamilton EJ (1947) War and prices in Spain. 1651-1800. Harvard University Press, Harvard. Spanish translation of L. Iglesias (1988), Alianza, Madrid

Harvey AC (1985) Trend and cycles in macroeconomic time series. Journal of Business \& Economic Statistics 3: 216-227

Harvey AC (1989) Forecasting structural time series models and the Kalman filter. Cambridge University Press, Cambridge

Harvey AC, Jaeger A (1993) Detrending and the business cycle. Journal of Applied Econometrics 8: 231-247

Harvey AC, Trimbur T (2008), Trend estimation and the Hodrick-Prescott filter. Journal of the Japan Statistical Society 38: 41-49

Llopis E, Jérez M, Álvaro A, Fernández E (2000) Índices de precios de la zona noroccidental de Castilla y León, 1518-1650. Revista de Historia Económica XVIII: 665-684 
Martín Aceña P (1992) Los precios en Europa durante los siglos XVI y XVII: estudio comparativo. Revista de Historia Económica X: 359-395

Munro J (2007) Review of Earl J. Hamilton, American treasure and the price revolution in Spain, 1501-1650. EH.Net Economic History Services. http://eh.net/book_reviews/american-treasure-and-the-price-revolution-in-spain1501-1650/. Accessed 15 March 2014

Murray CJ (2003) Cyclical properties of Baxter-King filtered time series. The Review of Economics and Statistics 85: 472-476

Nadal J (1959) La revolución de los precios españoles en el siglo XVI. Estado actual de la cuestión. Hispania, Revista Española de Historia 19: 503-529

Nelson CR (1988) Spurious trend and cycle in the state space decomposition of a time series with a unit root. Journal of Economic Dynamic and Control 12: 475-488

Phelps Brown EH, Hopkins SV (1956) Seven centuries of the prices of consumables, compared with builders' wage rates. Economica XXIII: 296-314

Reher DS, Ballesteros E (1993) Precios y salarios en Castilla la Nueva: la construcción de un índice de salarios reales, 1501-1991. Revista de Historia Económica XI: 101-151

Ruiz Martín F (1997) El problema del vellón: su incidencia en la distinta evolución económica de Castilla y de la Corona de Aragón en el siglo XVII. Manuscrits 15: $97-104$

Sargent TJ, Velde FR (2002) The big problem of small change. Princeton University Press, Princeton

Stock JH, Watson MW (1989) New indexes of coincident and leading economic indicators. In: NBER Macroeconomics Annual, MIT Press, Cambridge, pp 351394

Stock JH, Watson MW (1991) A probability model of the coincident economic indicators. In: Lahiri K, Moore GH (ed) Leading economic indicators. New approaches and forecasting records. Cambridge University Press, Cambridge

Velde FR, Weber WE (2000) Fiat money in seventeenth century Castile. Federal Reserve Bank of Chicago, Chicago

Watson MV (1986) Univariate detrending methods with stochastic trends. Journal of Monetary Economics 18: 49-75

Young PC (1994) Time-variable parameter and trend estimation in nonstationary economic time series. Journal of Forecasting 13: 179-210 


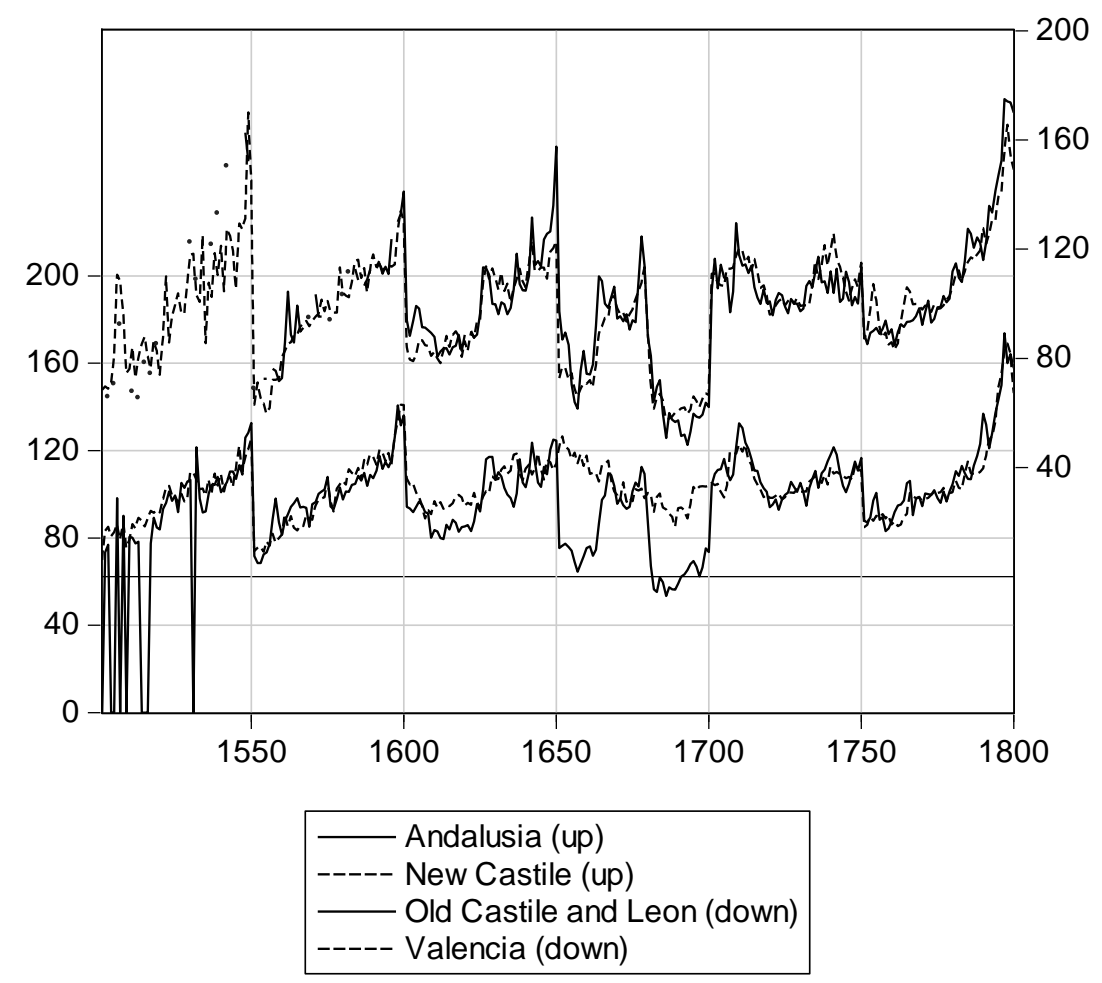

Fig. 1 Hamilton's original indexes. $1501=100$

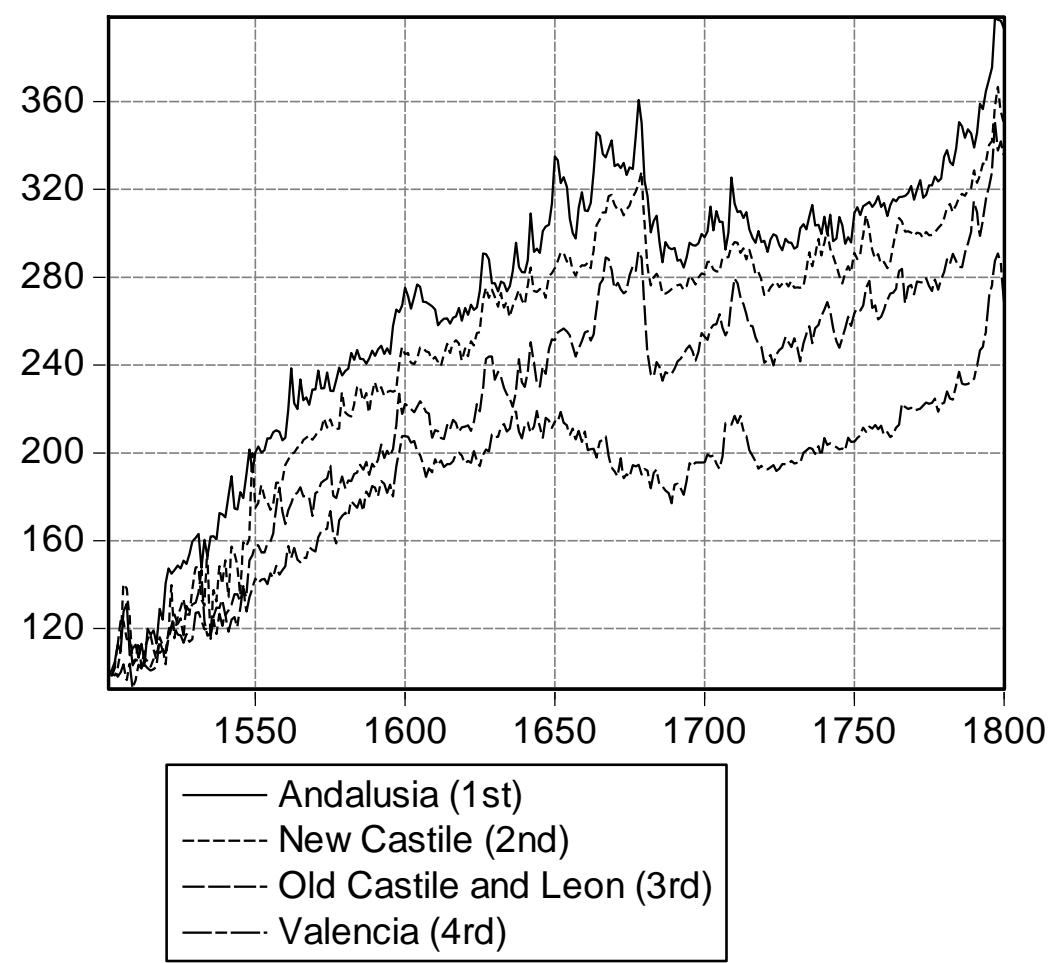

Fig. 2 Hamilton's indexes modified to correct for missing observations and base year changes. $1501=100$ 




Fig. 3 Smoothed trends of Hamilton's modified price indexes. 1501=100

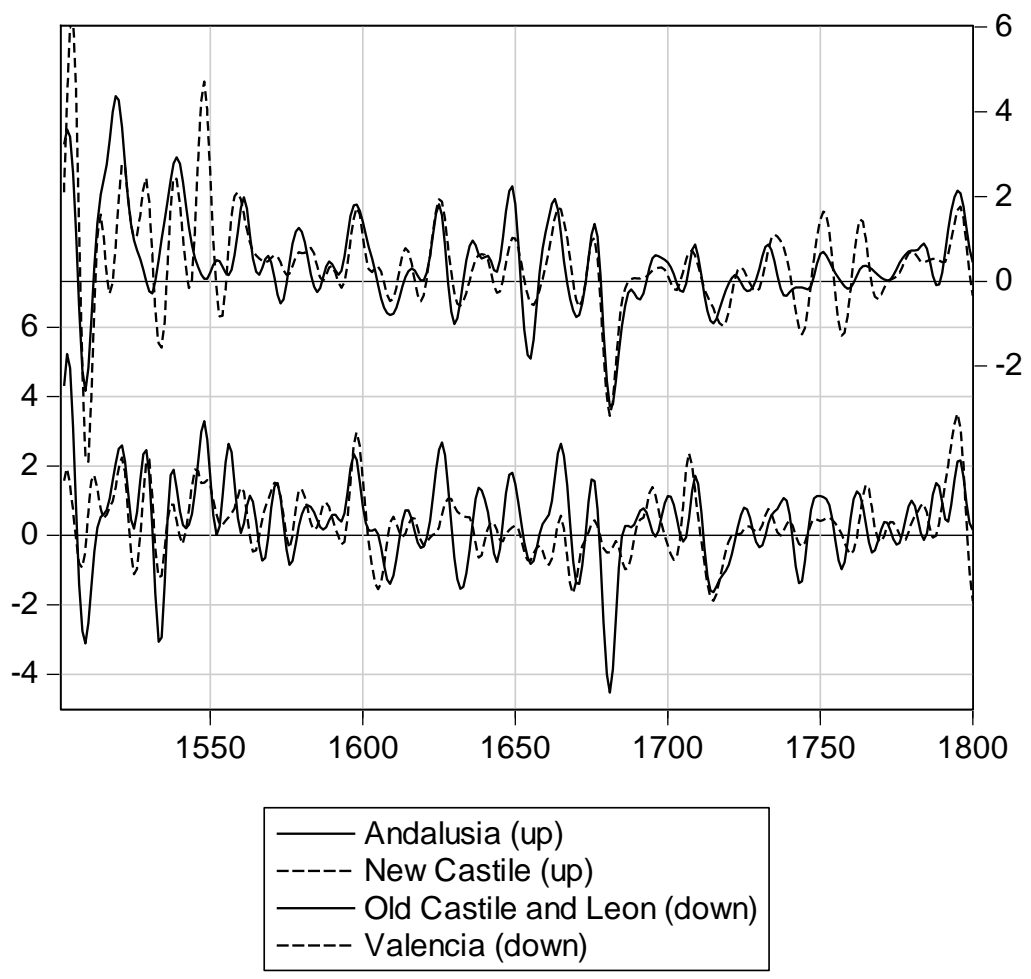

Fig. 4 Inflationary signals calculated from the smoothed trends of the cyclical trend model (1) (unit: percentage variation) 




Fig. 5 Inflationary signals calculated from the smoothed trends of the multivariate model with common cyclical factor (2) (unit: percentage variation)

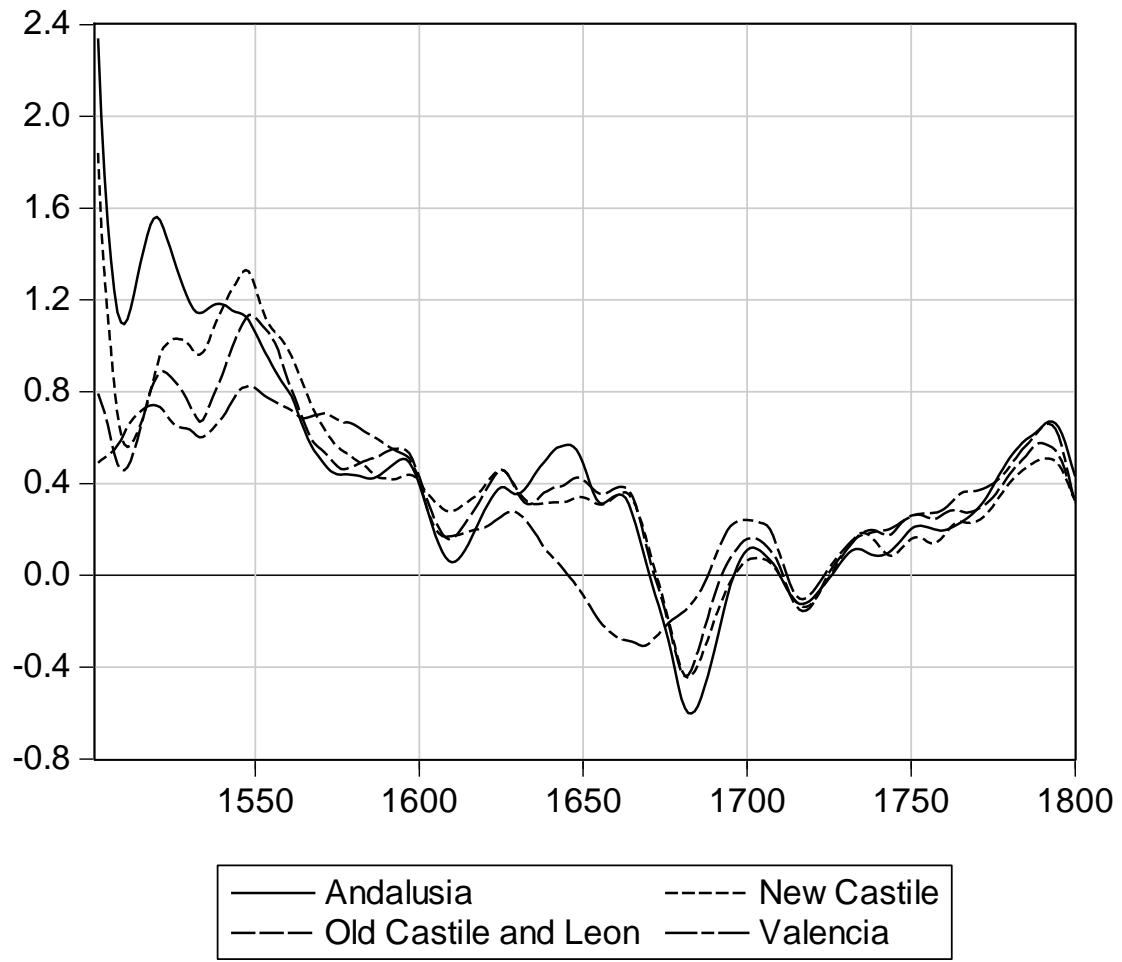

Fig. 6 Trend inflation rates (unit: percentage variation) 


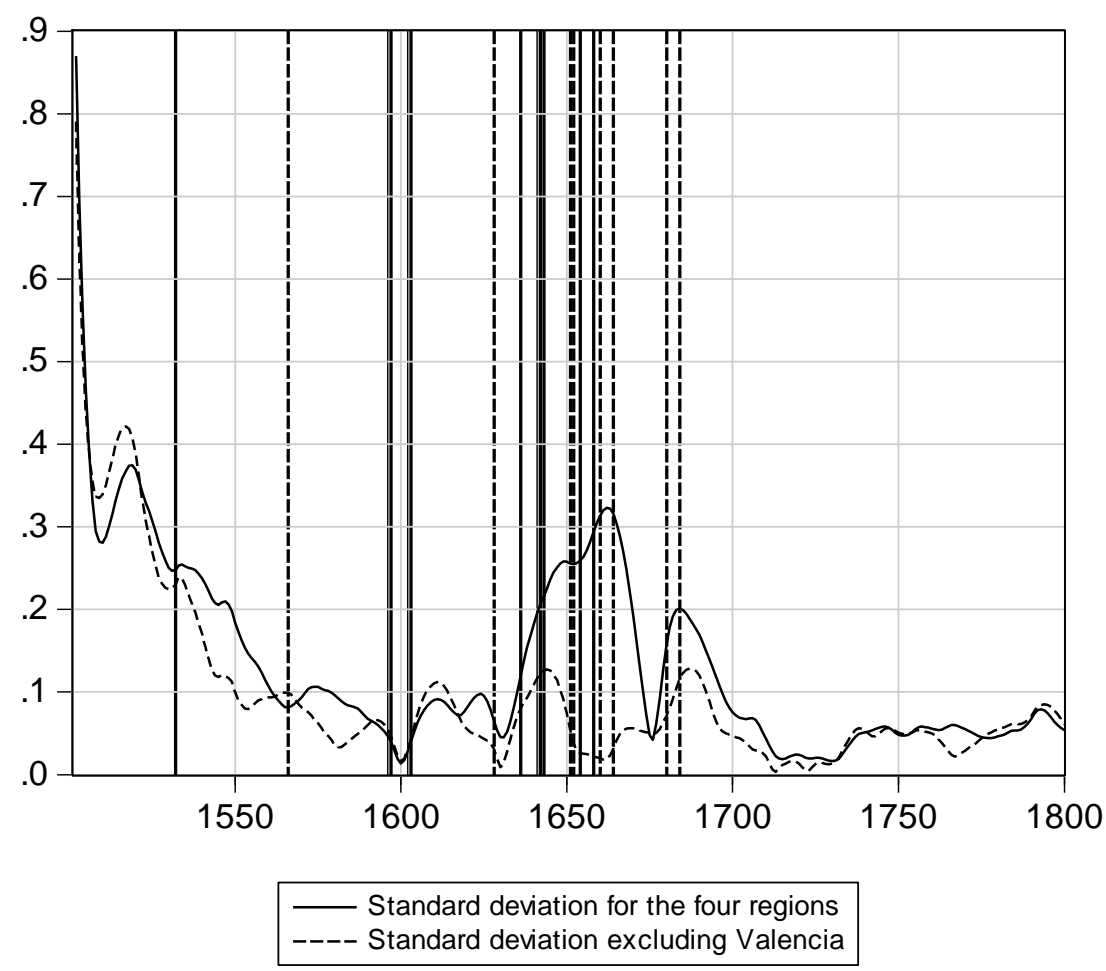

Fig. 7 Standard deviation of trend inflation 